\title{
DNA Damage-Binding Protein 1
}

National Cancer Institute

\section{Source}

National Cancer Institute. DNA Damage-Binding Protein 1. NCI Thesaurus. Code C93074.

DNA damage-binding protein 1 (1140 aa, $127 \mathrm{kDa})$ is encoded by the human DDB1 gene. This protein is involved in both protein ubiquitination and DNA damage repair. 